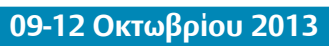

\title{
EUROSON 2013
}

Ev ó

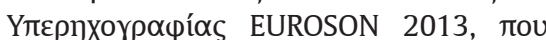

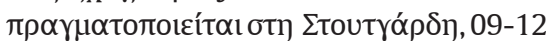

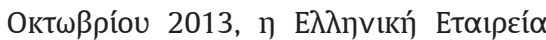

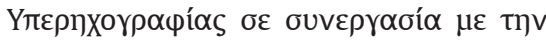

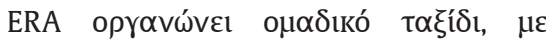

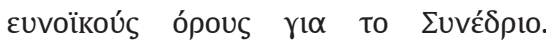

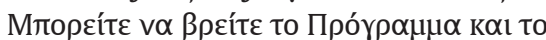

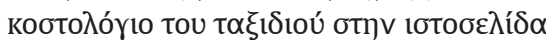

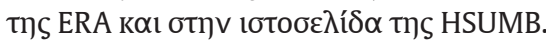

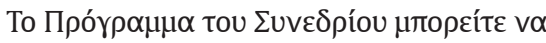

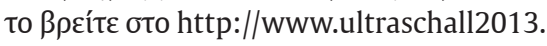
org/program.html ń бто site tns

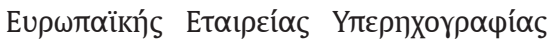
www.efsumb.org. $\Sigma \varepsilon \pi \varepsilon p i ́ \pi \tau \omega \sigma \eta \pi) ~ \pi 0 u ~ \sigma \alpha \varsigma$

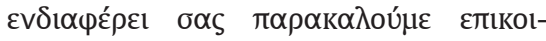

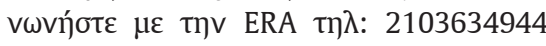
mail: info@ear.gr www.era.gr
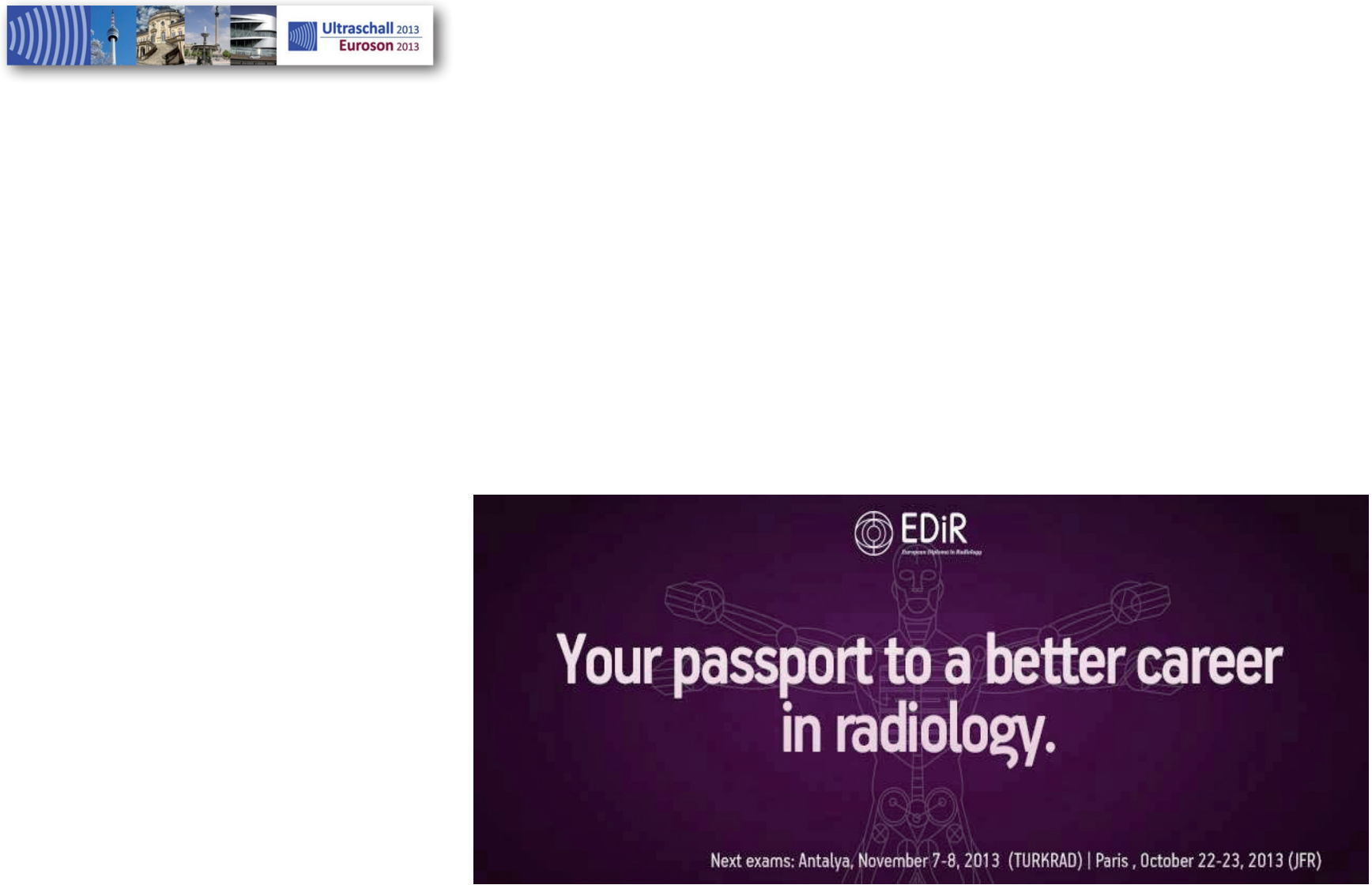